Тучковенко Ю. С., д-р геогр. наук, професор ${ }^{1}$

$(0000-0003-3275-9065)$

Кушнір Д. В., канд. геогр. наук ${ }^{1}$

(0000-0003-4556-0143)

Гончаренко Р. В. ${ }^{2}$

Титюк Т. Г. ${ }^{2}$

Щипцов О. А., д-р геогр. наук, професор ${ }^{3}$

(0000-0002-6285-0663)

1 - Одеський державний екологічний університет, Одеса;

2 - Центр навігації, гідрографії та гідрометеорології ВМС ЗС України, Одеса;

3 - ДУ “Науковий гідрофізичний центр Національної академії наук України”, Київ

\title{
Автоматизований модельний комплекс для забезпечення діяльності Військово-Морських Сил України оперативними прогнозами океанографічних умов
}

Резюме. У статті наведено опис структури та результати випробувань складових автоматизованого модельного комплексу для оперативного короткочасного прогнозування зміни океанографічних умов в акваторіях Чорного моря. Висвітлено перспективи використання поточної версії комплексу в інтересах навігаційно-гідрографічного забезпечення Військово-Морських Сил України.

Ключові слова: Чорне море; океанографічні умови; прогнозування; модельний комплекс; навігаційно-гідрографічне забезпечення, Військово-Морські Сили України.

Постановка проблеми. Унаслідок окупації Кримського півострова Російською Федерацією (РФ), у 2014 році Україна втратила національну автоматизовану систему морського прогнозування для Чорного та Азовського морів, яка була створена та функціонувала на базі Морського гідрофізичного інституту Національної академії наук України (м. Севастополь) за фінансовою та матеріально-технічною підтримкою Європейського Союзу $[1,2]$. Була припинена співпраця з Гідрометцентром РФ у галузі надання спеціалізованих морських прогнозів для Азово-Чорноморського басейну. Отже, вирішення проблеми відновлення функціонування сучасної національної системи оперативного прогнозу океанографічних параметрів стану морського середовища української частини акваторії Азово-Чорноморського басейну для забезпечення потреб морегосподарського комплексу, морської транспортної інфраструктури i, особливо, ВійськовоМорських Сил (ВМС) Збройних Сил (3С) України набуло особливої актуальності.

3 метою захисту власних національних інтересів і зміцнення регіональної безпеки Україна розвиватиме практичну взаємодію 3 державами-членами НАТО у гарантуванні безпеки в Чорноморському басейні [3]. На цьому етапі відбудови ВМС ЗС України реалізується стратегія “москітного флоту”, тобто комплектації бойового складу флоту малорозмірними кораблями типу "Гюрза-М”,
“Айленд”, а також у перспективі - "Марк VI" та ін. Безпека мореплавства та ефективність застосування такого флоту значною мірою визначаються гідрометеорологічними умовами як у районах дислокації кораблів, так i навігації, що обумовлює важливість надання якісного гідрометеорологічного забезпечення діяльності ВМС ЗС України відповідно до норм Альянсу.

Виконання завдання організації навігаційно-гідрографічного забезпечення, гідрометеорологічної підтримки повсякденної діяльності сил (військ) у структурі ВМС 3С України покладено на Центр навігації, гідрографіï та гідрометеорології. Гідрометеорологічна підтримка ВMC 3С України здійснюється 3 метою об'єктивного оцінювання та урахування гідрометеорологічних умов під час планування та проведення заходів бойової підготовки, використання даних для ефективного застосування зброї, бойової техніки, безпечного плавання кораблів, забезпечення морського десантування військ, захисту сил і об'єктів від зброї масового ураження, наслідків руйнування радіаційно, хімічно, біологічно небезпечних об'єктів та небезпечних $\mathrm{i}$ стихійних гідрометеорологічних явищ.

Аналіз останніх досліджень i публікацій. $\mathrm{y}$ таких державах-членах Альянсу, як Сполучені Штати Америки, Великобританія, Канада та ін. широко застосовуються інформаційні системи 
детального оперативного (швидкого) прогнозу океанографічних параметрів стану вод морського шельфу (відгінно-нагінних явищ, течій, морського хвилювання та ін.), засновані на сучасних інтегрованих чисельних математичних моделях [4-6].

3 огляду на вказане, актуальною $є$ задача розроблення інтелектуальної інформаційної системи висвітлення гідрографічної обстановки в акваторіях Чорного моря 3 використанням океанографічних даних $[7,8]$ в інтересах навігаційно-гідрографічного забезпечення 3С України, яка нині розв'язується під загальним керівництвом Державної установи “Науковий гідрофізичний центр Національної академії наук України”. Важливою складовою цієї системи має стати автоматизований програмний комплекс чисельних математичних моделей для оперативного короткочасного прогнозу мінливості океанографічних характеристик в акваторіях Чорного моря, попередня версія якого розроблена в Одеському державному екологічному університеті [9].

Основу автоматизованого програмного комплексу для прогнозування мінливості океанографічних характеристик акваторії Азово-Чорноморського басейну склали чисельні математичні моделі нового, порівняно $3[1,2]$ покоління, які на сьогодні успішно застосовуються для вирішення подібних прогностичних задач у країнах, розташованих на північно-західному шельфі Європи [4,5], в Австралії та Новій Зеландії [10], країнах Азії [11] i, зокрема, Океанографічним офісом оперативної підтримки Військово-Морських Сил США (NAVOCEANO) [6, 12-13] для прогнозування морського хвилювання та циркуляції вод у прибережних морських районах.

Мета статті полягає в описі структури, результатів верифікації і валідації складових автоматизованого модельного комплексу для оперативного короткочасного прогнозування зміни океанографічних умов в акваторіях Чорного моря, а також в обговоренні перспектив використання поточної версії такого комплексу в інтересах навігаційногідрографічного забезпечення ВMC ЗС України.

\section{Викладення основного матеріалу}

Загальний onuc структури автоматизованого модельного комплексу. Автоматизований модельний комплекс, який може використовуватись для вирішення задач як прогнозу, так і діагнозу океанографічних параметрів стану морського середовища в українській частині акваторії АзовоЧорноморського басейну, базується на використанні двох програмних модулів інтегрованого модельного комплексу Delft3D (розробник - науково-дослідний інститут прикладних досліджень Deltares, Нідерланди) [14]: FLOW та WAVE. Розробником надається вільний доступ широкому колу споживачів до кодів програмних пакетів, а їх використання регулюється ліцензійною угодою GNU General Public License верciï 3 [15].

Delft3D-FLOW - це базовий гідротермодинамічний модуль інтегрованого пакету програм Delft3D версіï 4.04.01, який дає змогу моделювати просторово-часову мінливість таких океанографічних характеристик, як термогалинна структура та густинна стратифікація морських вод; їх циркуляція, спричинена різними чинниками i їх сукупністю (густинні, градієнтні, вітрові, вітрохвильові та сумарні течіi); коливання рівня моря, спричинені дією вітру та атмосферного тиску; перенос (трасування) як консервативних, так i неконсервативних домішок у морському середовищі.

Модель Delft3D-FLOW базується на чисельному вирішенні тривимірних рівнянь Нав'є-Стокса для нестисливої рідини на мілкій воді у наближенні Бусінеска. Система диференційних прогностичних рівнянь моделі складається 3 рівнянь руху, рівняння нерозривності, рівнянь транспорту скалярних величин (тепла i солей) та двопараметричної $k$ - $\varepsilon$ моделі турбулентності, яка замикає ці рівняння [16]. Модель може бути налаштована на розрахунки за вертикальною координатою iз використанням як криволінійної $\sigma$-системи, $\begin{array}{llll}\text { так } & \text { п прямолінійної Z-системи. У }\end{array}$ $\sigma$-координатному налаштуванні передбачається гідростатичний потік, тоді як $\mathrm{Z}$-координатне налаштування може бути використане і для негідростатичного потоку.

Delft3D-WAVE - програмний модуль, у якому використовується спектральна модель 3-го покоління для розрахунку просторовочасової мінливості параметрів вітрового хвилювання SWAN (Simulating Waves Nearshore Model) [17]. Модель базується на чисельному вирішенні рівняння балансу енергіï хвиль у спектральній формі 3 урахуванням iii джерел $\mathrm{i}$ стоків. У SWAN реалізовані процеси, які пов'язані 3 генерацією, поширенням у просторі та дисипацією вітрових хвиль: передача енергії від вітру до хвиль (генерація хвиль вітром); поширення хвиль у просторі; рефракція хвиль 
i трансформація їх параметрів через просторові варіації глибин і течій; взаємодія хвиль і течій; дисипація хвильової енергії внаслідок донного тертя, обвалення гребенів (забурунювання) хвиль (whitecapping) та обвалення хвиль на критичних глибинах (wave breaking) через їх зміну; нелінійна взаємодія між хвилями як у глибокому морі (4-х хвильова), так і у мілкому морі (3-х хвильова).

Обидва програмні модулі реалізовані в горизонтальній площині на криволінійній розрахунковій сітці, інтегровані за допомогою взаємного інтерфейсу i взаємодіють між собою, тобто враховується вплив течій на параметри вітрового хвилювання та їх поширення i, навпаки, внесок хвильових процесів у формування прибережних течій та інтенсивність турбулентного змішування вод. Спільний прогноз вітрового хвилювання i циркуляції вод дає змогу підвищити точність розрахунків швидкості та напрямку морських течій, температури і солоності води у верхньому шарі моря. Поліпшення якості прогнозу досягається завдяки більш коректному обліку ефектів взаємодії морських хвиль i течій за умови використання комплексної прогностичної моделі цих явищ.

Модельний комплекс успішно працює як на розрахункових моносітках, так і на складових мультисітках, що допомагає оптимізувати використання обчислювальних ресурсів і мінімізувати час обчислювального процесу. Крім використання складових розрахункових сіток, в модельному комплексі передбачена можливість телескопізації обчислювального процесу на більш деталізовану сітку для будь-якої досліджуваної області всередині загальної розрахункової області. Такий підхід дає змогу прискорювати обчислювальний процес i мінімізувати зайнятість обчислювального ресурсу.

За допомогою загального інтерфейсу формуються граничні умови на відкритих бічних межах розрахункових областей, задаються керуючі параметри моделей i вибираються методи апроксимації підсіткових процесів.

Програмні коди моделей Delft3D-FLOW i SWAN, скомпільовані у файли, які виконуються, за допомогою компіляторів Visual Fortran i C++, запускаються послідовно на тих самих криволінійних розрахункових сітках i використовують весь набір ядер процесора комп'ютерної станції (або вузлів обчислювального кластера). Під час проведення гідродинамічних розрахунків, модель Delft3D-FLOW розбиває задачу для іï паралельного виконання на процесорних ядрах (вузлах) за допомогою програмного інтерфейсу Message Passing Interface (MPI). Модель SWAN (модуль WAVE) під час розрахунків за замовчуванням використовує паралельні обчислення на всіх ядрах процесора відповідно до стандарту OpenMP (Open Multi-Processing).

Під час виконання чисельного прогностичного моделювання в інтегрованому режимі розрахунків, модуль WAVE (модель SWAN) отримує, в режимі онлайн, розраховані гідродинамічним модулем FLOW поля течій, рівня моря, зональних i меридіональних компонент швидкості вітру для обчислення параметрів трансформації хвиль. Розраховані модулем WAVE параметри вітрового хвилювання передаються в онлайн режимі (із встановленою користувачем часовою дискретністю) до гідродинамічного модуля для подальших розрахунків рівня моря, стратифікації і течій.

Океанографічний прогноз надається на підставі метеорологічного прогнозу на 10 діб з часовою дискретністю 3 години за глобальною чисельною моделлю прогнозу погоди GFS (Global Forecast System), вебсервіс якої (National Operational Model Archive and Distribution System - NOMADS), знаходиться в США [18]. Просторова деталізація прогностичних даних моделі GFS у горизонтальній площині становить $0,25^{\circ}$ за широтою та довготою. Національна метеорологічна служба США надає безкоштовний доступ до прогностичних даних моделі GFS. Оперативні поточні прогнози метеорологічних параметрів зчитуються 3 вебресурсу NOMADS (Data Transfer: NCEP GFS Forecasts (0,25 degree grid) [19]. Окрім того, усі вироблені за останні декілька років у вказані строки прогнози зберігаються в історичному архіві GFS-прогнозів на відповідному вебресурсі (NCEP GFS 0,25 Degree Global Forecast Grids Historical Archive) [20] Національного центру атмосферних досліджень США (National Center for Atmospheric Research, NCAR) і можуть бути вільно зчитані. Прогностична продукція за моделлю GFS використовується, зокрема, в оперативній діяльності Українського гідрометеорологічного центру.

Для використання користувачами, модельний комплекс Delft3D-FLOW + SWAN оснащений сервісною оболонкою з графічним інтерфейсом. Ця оболонка автоматизує процедуру зчитування метеорологічної 
інформації 3 вебсервісу NOMADS, iï фільтрацію та підготовку до використання під час моделювання океанографічних параметрів, максимально спрощуе для користувача процедури особистого налаштування роботи програмних модулів Delft3D-FLOW i Delft3D-WAVE (SWAN), розрахунків за ними на вкладених деталізованих у просторі сітках (процедура NESTING), візуалізацію вхідних метеорологічних даних $\mathrm{i}$ результатів оперативного прогнозування океанографічних характеристик (із використанням програмного модуля QUICKPLOT).

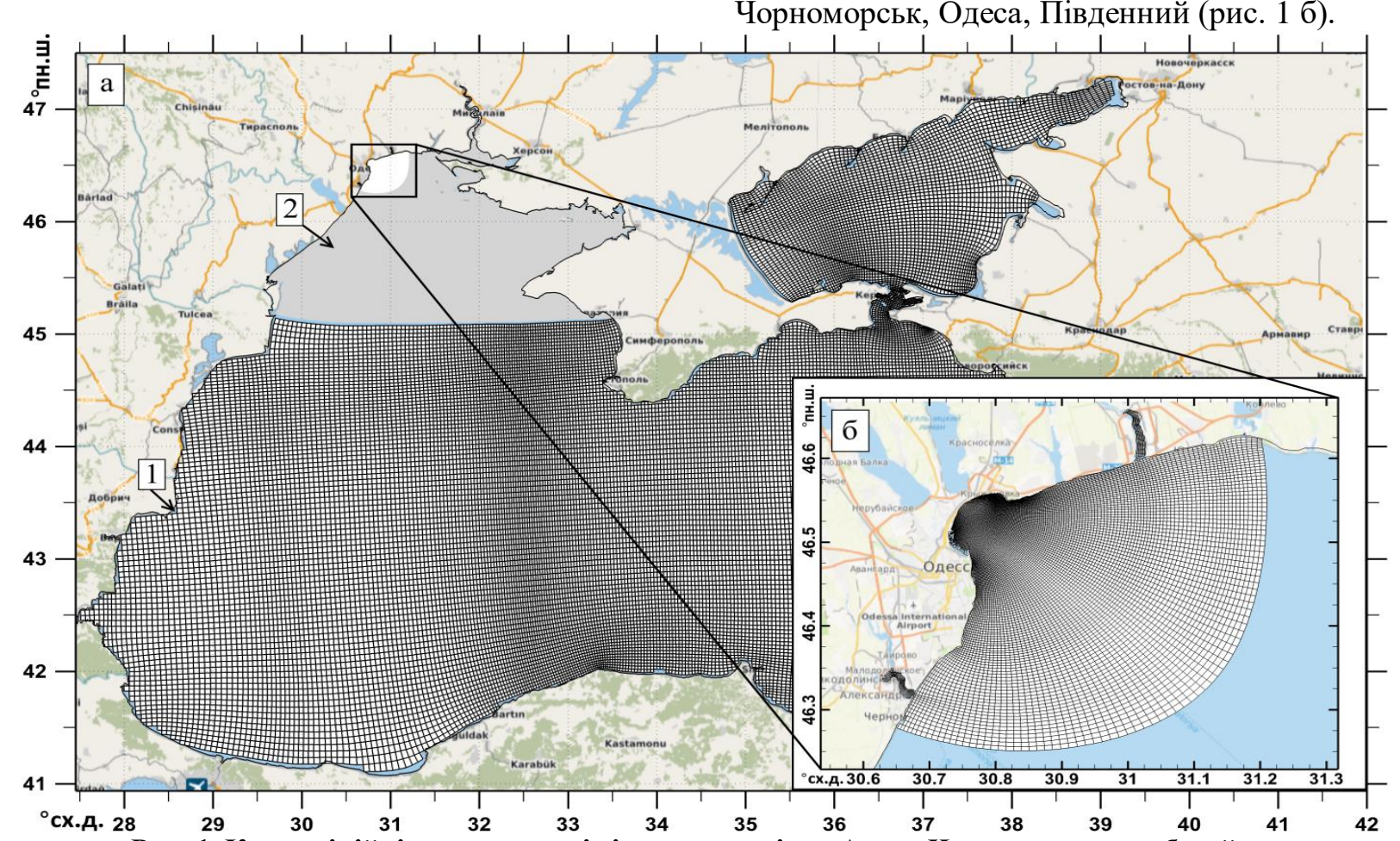

Рис. 1. Криволінійні розрахункові сітки для регіону Азово-Чорноморського басейну:

а - базова розрахункова сітка $\left(\Delta_{x y}=2,5-5 \kappa м\right)(1)$ та деталізована розрахункова сітка для північно-західної частини Чорного моря ( $\left.\Delta_{x y}=800 м-1,5 \kappa м\right)(2)$;

б - вкладена сітка для морської акваторії Одеського району північно-західної частини Чорного моря

Результати випробувань прогностичного комплексу. Успішне застосування чисельних математичних моделей для вирішення прогностичних океанографічних задач передбачає виконання процедур їх адаптації до умов досліджуваних акваторій, верифікації та валідації.

Верифікація модельного комплексу виконувалась за допомогою порівняння результатів моделювання 3 даними спостережень за мінливістю рівня моря на морських гідрометеорологічних станціях Гідрометцентру Чорного та Азовського морів у портах Чорноморськ, Одеса, Південний і даними реєстрації дрейфових течій, характеристик вітрового хвилювання на гідрометеорологічному буї SW Midi-185 (виробництва Fugro
В актуальній версії автоматизованого програмного комплексу розрахунки попередньо виконуються на генералізованій сітці 3 просторовим розділенням $\Delta_{x y}=2,5-5 \kappa м$ для всього АзовоЧорноморського басейну (рис. 1). Усередині базової розрахункової сітки згенеровані вкладені розрахункові сітки 3 більшою деталізацією: $\Delta_{x y}$ в межах 800 м - 1,5 км - для північно-західної частини Чорного моря (2 на рис. 1a) i 90 - 250 м - для акваторії Одеського району північно-західної частини Чорного моря, де розташовані морські порти Чорноморськ, Одеса, Південний (рис. 1 б). 
прогнозу погоди GFS через вебсервіс NOMADS

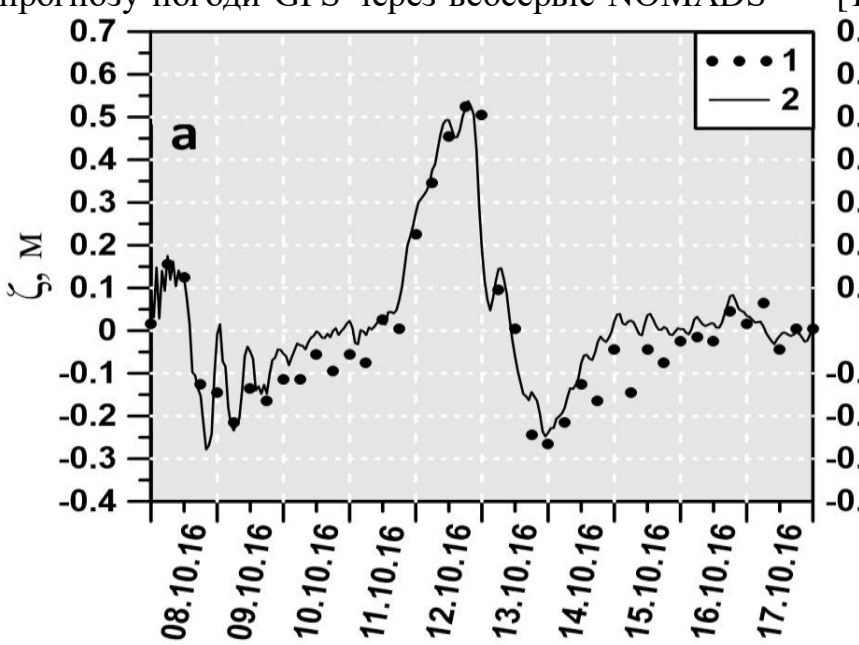

[18].

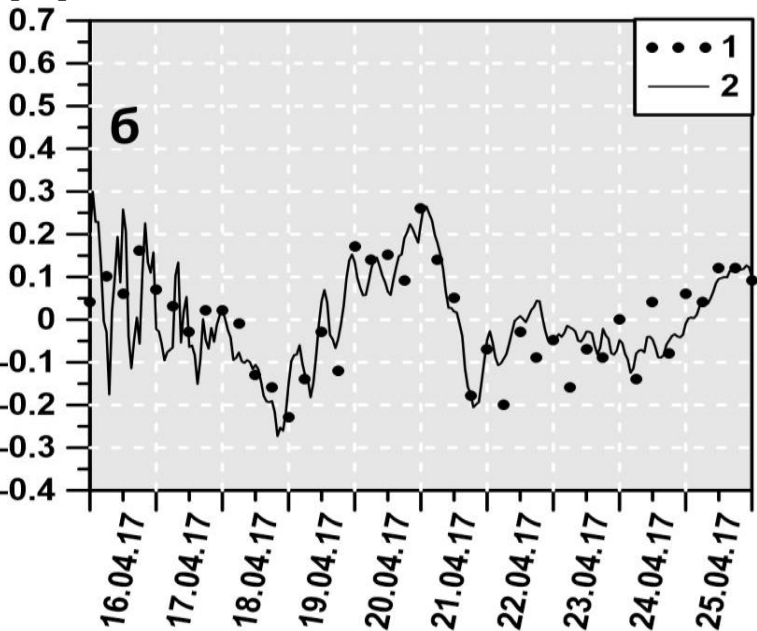

Рис. 2. Мінливість викликаних вітром денівеляцій рівня моря, м, за даними спостережень (1) і отримана в результаті моделювання (2) в порту Чорноморськ у розрахункові періоди

(a) $-08.10-18.10 .2016$

(б) $-16.04-25.04 .2017$

До того ж використовувалась така процедура зчитування даних, яка максимально наближала їх до ре-аналізу, але 3 більш детальним просторовим розділенням $\left(0,25^{\circ}\right.$ замість $0,5^{\circ}$ за широтою і довготою). Модель GFS запускається чотири рази на добу - у 00:00, 6:00, 12:00 і 18:00 годин UTC. Кожного разу під час запуску модель генерує прогностичні поля метеорологічних величин 3 3-х годинною часовою дискретністю на період від 0 до 24 год. Оскільки на цьому етапі роботи архів GFS-прогнозів використовувався для верифікації чисельних математичних моделей Delft3D-FLOW i SWAN, то в кожен з основних термінів запуску моделі GFS протягом доби (4 рази на добу) зчитувався прогноз тільки на найближчі 6 годин.

Отримані під час верифікації комплексу інтегрованих чисельних математичних моделей Delft3D-FLOW + SWAN результати показали, що цей комплекс має хороші перспективи використання в системі оперативного прогнозу океанографічних параметрів стану морського середовища української частини акваторії АзовоЧорноморського басейну $\mathrm{y}$ варіанті із засвоєнням прогностичної метеорологічної інформації, одержаної за допомогою глобальної атмосферної моделі GFS.

Валідація модельного комплексу здійснювалась шляхом вирішення задач прогнозування 3 різною завчасністю викликаних штормовими вітрами відгіннонагінних коливань рівня моря та висоти вітрових хвиль в акваторії Одеського району північно-західної частини Чорного моря i порівняння їх зі спостереженими значеннями. На відміну від імітаційних розрахунків для верифікації моделі, застосовувалась така процедура зчитування метеорологічних даних 3 архіву GFS-прогнозів [20]. Прогноз відгіннонагінних коливань рівня моря та параметрів вітрового хвилювання надавався на 10 діб. Для відтворення модельним комплексом передісторії прогнозу викликаних вітровою дією змін океанографічних характеристик та адаптації моделі до вхідних метеоданих, які передують даті прогнозу, зчитування даних 3 архіву GFS-прогнозів здійснювалось за описаною вище процедурою, яка використовувалась під час верифікації моделі. Далі, для вироблення прогнозу на наступні прогностичні 10 діб, зчитувались суто прогностичні дані з інтервалом у часі 3 години та 3 просторовим розділенням координатної сітки 0,25 градусів за широтою та довготою.

Окремі результати випробування модельного комплексу у прогностичному режимі, із використанням даних синоптичного прогнозу мінливості вітрових умов над Чорним морем, отриманих за глобальною атмосферною моделлю GFS, наведено на рис. 4. Результати випробувань свідчать, що прогноз викликаних вітром денівеляцій рівня моря, висот вітрових хвиль із завчасністю до 4 діб добре узгоджується 3 даними спостережень у разі відсутності значних похибок у метеорологічному прогнозі, зокрема, вітрових умов за моделлю GFS. 

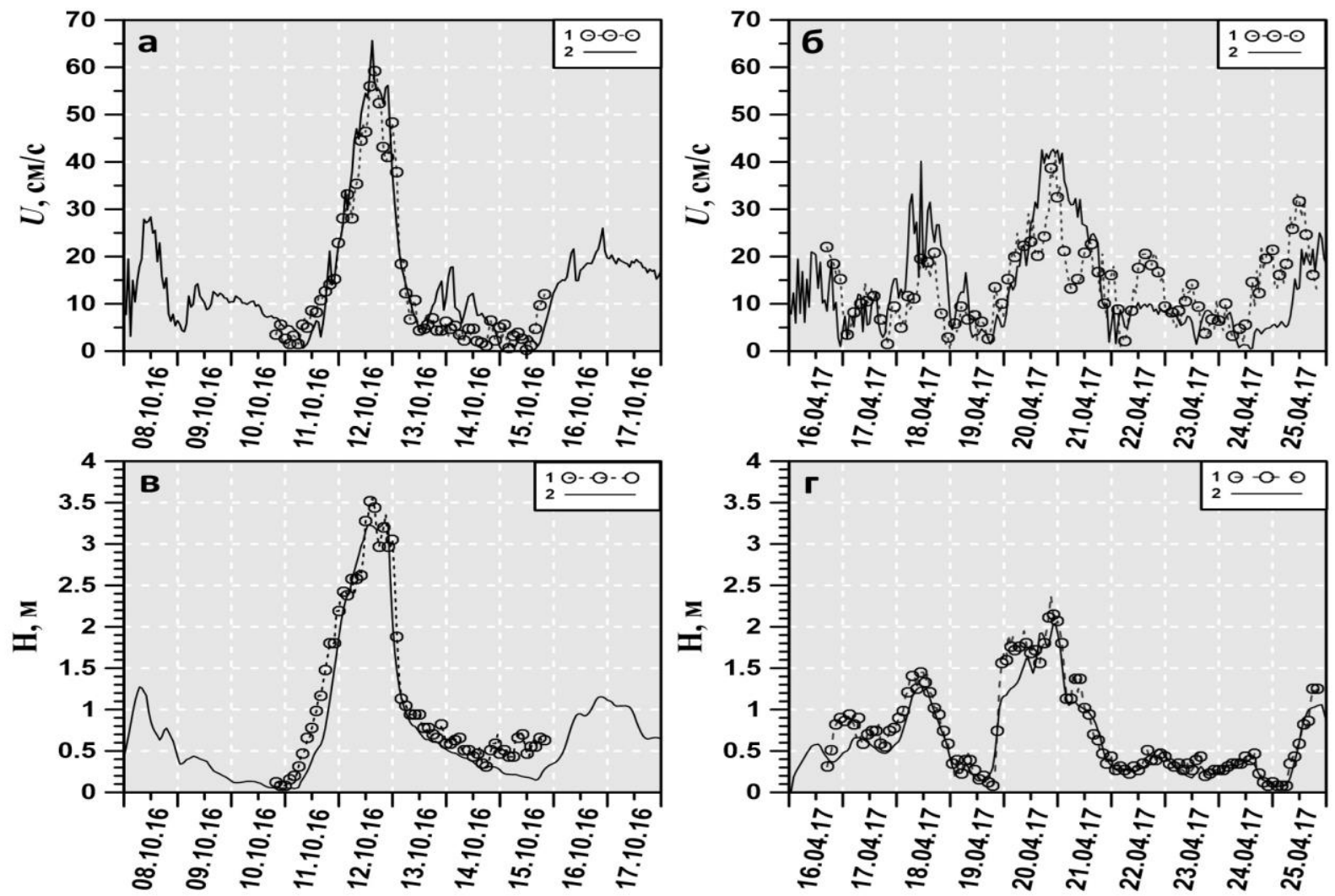

Рис. 3. Часова мінливість швидкості дрейфової течії (а, б), см/с, та висот вітрових хвиль (в, г), м, у розрахункові періоди 08.10-18.10.2016 та 16.04-26.04.2017

1 - за даними вимірів на гідрометеорологічному буі;

2 - отримана в результаті моделювання

Перспективи використання автоматизованого прогностичного комплексу в інтересах навігаиійно-гідрографічного забезпечення ЗС Украӥни. Застосування автоматизованого модельного комплексу для оперативного прогнозування короткострокової просторово-часової мінливості океанографічних характеристик у структурі інтелектуальної інформаційної системи висвітлення гідрографічної обстановки в акваторіях Чорного моря дасть змогу в перспективі вирішувати такі завдання в інтересах навігаційно-гідрографічного забезпечення Збройних Сил України:

вивчення морської операційної зони та районів застосування підрозділів $\mathrm{BMC}$ у навігаційному та гідрографічному відношенні; оцінювання впливу океанографічної обстановки на заплановані дії, надання рекомендацій щодо урахування цього впливу під час планування дій сил ВМС; оперативного

оцінювання океанографічної (навігаційно-гідрографічної) обстановки в зонах відповідальності ВМС і впливу іï на безпеку плавання, застосування зброї, використання техніки та технічних засобів;

забезпечення

оцінювання, очікуваної океанографічної обстановки штабів i сил ВМС, своєчасне доведення попереджень про небезпечні і стихійні гідрометеорологічні явища;

використання

національного прогностичного модельного комплексу 3 детальною просторово-часовою роздільною здатністю для складання спеціальних прогнозів в окремих прибережних районах виконання завдань; оперативного

оцінювання (прогнозування) поточних океанографічних умов у визначених районах моря та у визначений час під час виконання пошуковорятувальних операцій.

Актуальна версія автоматизованого модельного комплексу Delft3D-FLOW i SWAN налаштована на розрахунок мінливості океанографічних параметрів викликаних дією вітру: вітрового хвилювання, відгіннонагінних коливань рівня моря, вітрових i вітрохвильових течій. Оскільки зчитування даних метеорологічного прогнозу передбачено в структурі графічного інтерфейсу модельного комплексу, то в такому варіанті функціонування він не потребує отримання вхідної інформації від інших складових зазначеної інтелектуальної прогнозування і оповіщення щодо фактичної і 
інформаційної системи, тобто в цьому сенсі є

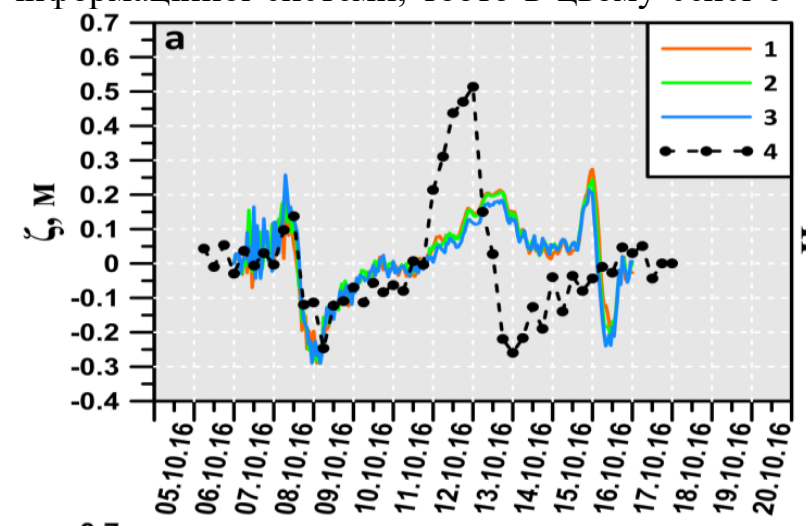

автономним.
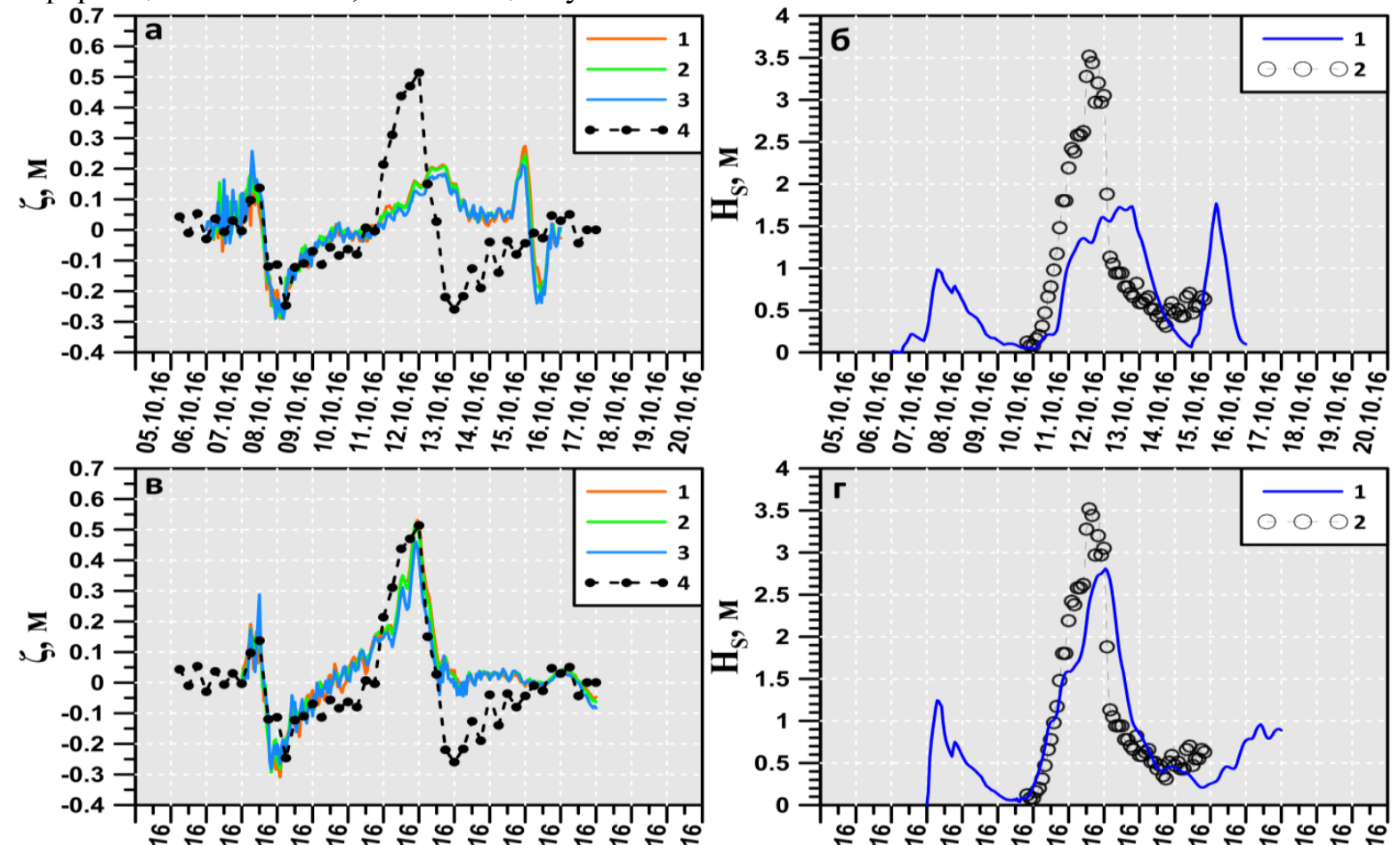

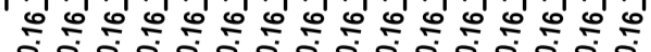

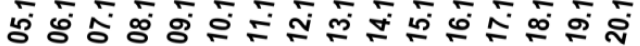

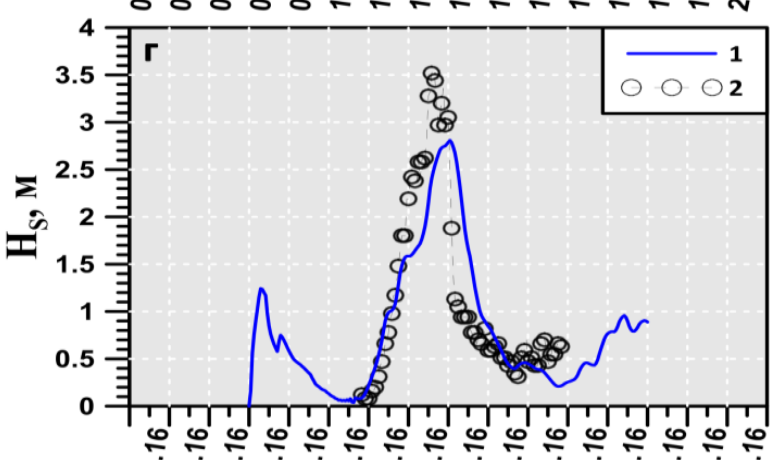

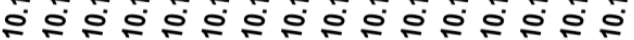

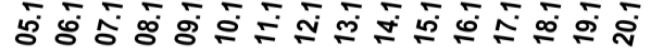

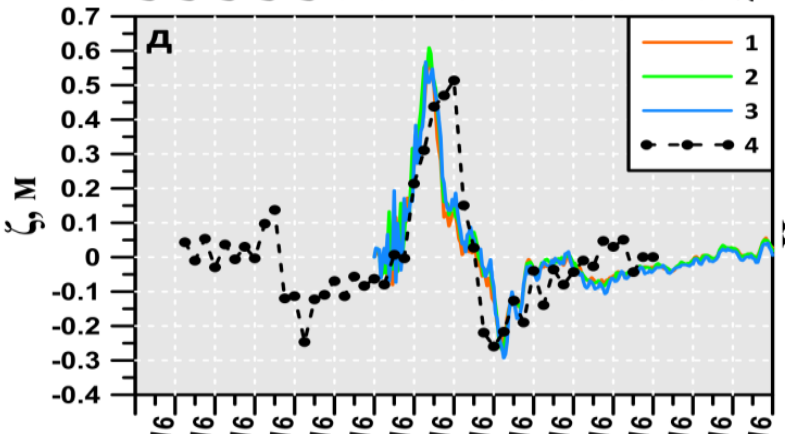

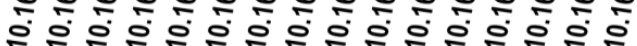

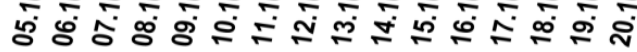

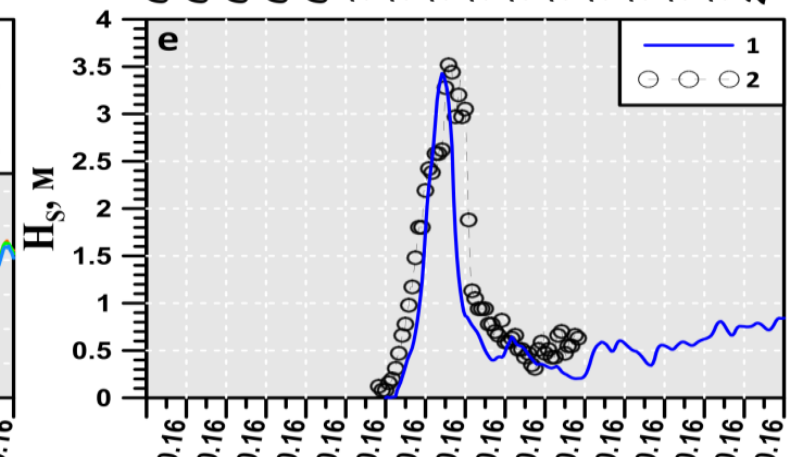

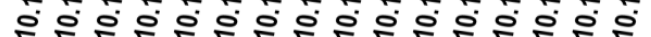

ति वें

Рис. 4. Часова мінливість денівеляцій рівня моря (а, в, д), м, та значних висот хвиль (б, г, е), м, за результатами моделювання (криві) та за даними спостережень (точки)

1 - порт Чорноморськ, 2 - порт Одеса, 3 - порт Південний);

відхилення від середнього значення за період для прогнозів із різною упередженістю вироблені у такі дати: $\boldsymbol{a}, \boldsymbol{\sigma}-07.10 .2016 ; \boldsymbol{b}, \boldsymbol{z}-08.10 .2016 ; \boldsymbol{\partial}, \boldsymbol{e}-11.10 .2016$

Результати розрахунків можуть містити як передісторію розвитку океанографічної ситуації (до 5 діб, але 3 можливістю збільшення відповідно до потреб), так i прогноз розвитку океанографічної ситуації на 10 діб уперед від дати прогнозу (достовірно до 4 діб).

В актуальній версії автоматизованого прогностичного комплексу виконання розрахунків 3 просторовою деталізацію в декілька сотень метрів $\left(\Delta_{x y}=90-250 м\right)$ передбачено тільки для Одеського району північно-західної частини Чорного моря (підходи до морських портів Чорноморськ, Одеса, Південний). У разі потреби в отриманні деталізованих у просторі

результатів розрахунків океанографічних характеристик для інших ділянок узбережжя Чорного моря (наприклад, вірогідних районів виконання учбових i бойових задач ВМС ЗС України в прибережних зонах моря), необхідно визначити такі ділянки на місцевості, додатково згенерувати для них криволінійні розрахункові сітки і здійснити налаштування роботи програмного комплексу за процедурою NESTING.

Висновки. Результати верифікації i валідації комплексу інтегрованих чисельних математичних моделей Delft3D-FLOW+SWAN свідчать про те, що цей комплекс має добрі перспективи використання в системі оперативного прогнозу мінливості океанографічних параметрів стану морського 
середовища української частини акваторії Азово-Чорноморського басейну у варіанті 3 використанням прогностичної метеорологічної інформації, яка одержується за допомогою глобальної атмосферної моделі GFS.

Оперативна океанографічна інформація, яка може бути отримана в результаті застосування автоматизованого програмного комплексу Delft3D-FLOW+SWAN, сприяє підвищенню безпеки навігації, особливо в мілководних прибережних i пригирлових районах моря, на підходах до морських портів та інших районів базування кораблів ВMC, підвищенню ефективності пошуковорятувальних операцій через врахування поточних (оперативних) та очікуваних гідрометеорологічних умов, i, особливо, картини розподілу течій, які визначають переміщення у просторі об'єктів із різною плавучістю, включно 3 вітровим дрейфом.

у термінах i визначеннях понять стандарту НАТО “Союзна спільна доктрина 3 метеорологічного та океанографічного забезпечення об'єднаних сил" [21], інтеграція автоматизованого модельного комплексу Delft3D-FLOW+SWAN у структуру інтелектуальної інформаційної системи висвітлення гідрографічної обстановки в акваторіях Чорного моря дає змогу вирішувати завдання оперативного (швидкого) оцінювання стану навколишнього (морського) середовища під час планування та проведення військових операцій протягом тактично вивірених проміжків часу, шляхом надання інформації щодо океанографічної обстановки в теперішньому (з передісторією до 5 днів) та майбутньому (до 4 днів) часі для всього Чорного моря, його північно-західної частини та обраних ділянок прибережних зон моря 3 необхідним просторовим розділенням даних. До набору океанографічних даних, які можуть бути отримані 3 використанням актуальної версії автоматизованого модельного комплексу Delft3D-FLOW+SWAN, відносяться: вітрові умови, відхилення рівня моря від незбуреного стану під дією вітру в прибережних зонах моря (які визначають поточні глибини), просторовачасова мінливість параметрів вітрового хвилювання, циркуляції вод (течій) у прибережних районах моря 3 урахуванням впливу вітрових хвиль.

Перспективи подальших досліджень. Архітектура графічного інтерфейсу дає змогу включити в розрахунки додаткові гідрофізичні процеси, пов'язані 3 просторово-часовою мінливістю температури та солоності води. Це дасть змогу отримувати оцінки мінливості вертикальної стратифікації вод (глибини верхнього квазіоднорідного шару перемішування вод, розташування та характеристики пікнокліну), враховувати окремо густинні та сумарні (густинні+вітрові) течії, розраховувати акустичні характеристики на ділянках акваторії моря, що моделюються. Проте в цьому випадку з банку океанографічних даних $[7,8]$ інтелектуальної системи потрібно зчитати i підготувати для використання у відповідному форматі дані щодо початкового тривимірного розподілу температури і солоності в розрахунковій області, витрат річкового стоку (наприклад, у першому наближенні, щомісячні поля температури і солоності морської води, ряди витрат стоку річок Дунай, Дніпро та Південний Буг, Дністер за багаторічними або поточними даними спостережень).

\section{СПИСОК ВИКОРИСТАНОЇ ЛІТЕРАТУРИ}

1. Kubryakov A. S., $\quad$ Korotaev G. K., Dorofeev V. L., Ratner Y. B., Palazov A., Valchev N., Malciu V., Matescu R., Oguz T. Black Sea coastal forecasting system. Ocean Sci. 2012. № 8. P. 183-196. DOI: https://doi.org/10.5194/os-8-183-2012.

2. Коротаев Г. К., Демышев С. Г., Дорофеев В. Л. и др. Архитектура и результаты работы международного Черноморского центра морских прогнозов, созданного на базе МГИ НАН Украины в рамках проекта Европейского Союза "Мой Океан". Екол. безпека прибер. та шельф. зон та компл. викор. ресурсів шельфу. 2013. Вип. 27. С. 128-133.

3. Про рішення Ради національної безпеки і оборони України від 14 вересня 2020 року "Про Стратегію національної безпеки України” : Указ Президента України від 14.09.2020 р. № 392/2020. Урядовий кур'єр. 2020. 16 верес. (№ 179).

4. SWEEP (2019). Co-creating Operational and Strategic Modelling Systems to Reduce Economic and Social Impacts on Coastal Hazards: Wave modelling. Project summary. URL: https://sweep.ac.uk/wp-content/uploads/ IP-001-A4-ESummary.pdf (дата звернення: 26.09.2020).

5. Apecechea M. I., Verlaan M., Zijl F., Le Coz C. \& Kernkamp H. (2017). Effects of self-attraction and loading at a regional scale: a test case for the Northwest European Shelf. Ocean Dynamics. , No 67 (6). pp. 729-749. URL: https://link.springer.com/article/10.1007/s10236-0171053-4 (дата звернення: 26.09.2020).

6. Veeramony J., Orzech M. D., Edwards K. L., Gilligan M., Choi J., Terrill E. and Tony De Paolo. Navy nearshore ocean prediction systems. Oceanography. 2014. Vol. 27. No 3. pp. 80-91.

7. Щипцов О. А., Щипцов О. О. Перспективи формування міжвідомчого банку цифрових океанографічних даних в інтересах навігаційногідрографічного забезпечення морської діяльності. Морська стратегія держави. Розвиток та реалізачія морського потенціалу України : матеріали міжнар. наук. форуму, м. Київ, 20-21 черв. 2018 р. Київ, 2018. C. $19-24$.

8. Щипцов О. А. Удосконалення міжвідомчої системи збору та використання океанографічної інформації щодо обстановки в Азово-Чорноморському басейні та інших районах Світового Океану. Морська стратегія держави. Розвиток та реалізачія морського потенціалу України : матеріали міжнар. наук. форуму, м. Київ, 22-23 трав. 2019 р. Київ, 2019. С. 5558.

9. Кушнир Д. В., $\quad$ Тучковенко Ю. С., $\quad$ Попов Ю. И. Результати адаптації та верифікації комплексу 
інтегрованих чисельних моделей для прогнозування мінливості океанографічних характеристик в північносхідній частині Чорного моря. Украӥнський гідрометеорологічний журнал. 2019. № 23. С. 95-108 DOI: https://doi.org/10.31481/uhmj.23.2019.09.

10. De Kleermaeker, Simone; Verlaan, Martin; Mortlock, Thomas; Rego, Joao Lima; Apecechea, Maialen Irazoqui; Yan, Kun and Twigt, Daniel (2017). Global-to-local scale storm surge modelling on tropical cyclone affected coasts. In: Australasian Coasts \& Ports 2017: Working with Nature. Barton, ACT: Engineers Australia, PIANC Australia and Institute of Professional Engineers New Zealand, 2017: 358-364. ISBN: 9781922107916. URL: https://search.informit.com.au/documentSummary; $\mathrm{dn}=934$ 516484243698; res=IELENG (дата звернення: 24.09.2020).

11. Thanathanphon, Watin: Luangdilok, Narongrit: Sisomphon, Piyamarn (2016) Development of an Operational Storm Surge Forecasting System for the Gulf of Thailand. 12th International Conference on Hydroscience \& EngineeringHydro-Science \& Engineering for Environmental Resilience. November 610, 2016, Tainan, Taiwan. URL: http://mdide.baw.de/icheArchive/documents/2016/12-0021.pdf (дата звернення: 24.09.2020).

12. Veeramony J., Condon A. J., Linzell R. S., \& Watson K. (2016). Validation of Delft3D as a Coastal Surge and Inundation Prediction System. Scientific Report. Naval Research Laboratory. Oceanography Division. Stennis Space Center, MS 39529-5004. URL: https://pdfs.semanticscholar.org/bbf0/18c6db02bcf8d63a4 8542637d531e788c32a.pdf (дата звернення: 24.09.2020).

13. Veeramony J., Condon A., van Ormondt M. Forecasting Storm Surge and Inundation: Model Validation. Weather and Forecasting. 2017. No 32 (6). pp. 2045-2063. DOI: https://doi.org/10.1175/waf-d-17-0015.1.

14. Delft3D Open Source Community. URL: https://oss.deltares.nl/web/delft3d/home (дата звернення 26.09.2020).

15. Terms of use Delft3D Community. URL: https://oss.deltares.nl/web/delft3d/terms-of-use (дата звернення 26.09.2020).

16. Deltares (2020). Delft3D-FLOW, User Manual: Simulation of multi-dimensional hydrodynamic flow sand transport phenomena, including sediments. 682 p. URL: https://content.oss.deltares.nl/delft3d/manuals/Delft3D-

FLOW_User_Manual.pdf (дата звернення 06.10.2020).

17. Deltares (2020). Delft3D-WAVE, User Manual: Simulation of short-crested waves with SWAN. 196 p. URL: https://content.oss.deltares.nl/delft3d/manuals/ Delft3D-WAVE_User_Manual.pdf (дата звернення 06.10.2020).

18. NOAA, National Operational Model Archive and Distribution System (NOMADS). URL: https://nomads.ncep.noaa.gov/ (дата звернення 07.03.2020)

19. NOMADS. Data Transfer: NCEP GFS Forecasts $(0.25$ degree grid). URL: http://nomads.ncep.noaa.gov/cgibin/filter_gfs_0p25.pl. (дата звернення 25.11.2019).

20. NCAR. Research Data Archive at the Computational and Information Systems Laboratory. NCEP GFS 0.25 Degree Global Forecast Grids Historical Archive. URL: https://rda.ucar.edu/datasets/ds084.1/ (дата звернення 25.11.2019).

21. NATO - AJP-3.11 ALLIED JOINT DOCTRINE FOR METEOROLOGICAL AND OCEANOGRAPHIC SUPPORT TO JOINT FORCES. URL: https://standards.global spec.com/std/10054861/AJP-3.11 (дата звернення 07.10.2020).

Стаття надійшла до редакційної колегії 31.10.2020

\section{An automatized modeling complex to support the activity of the Naval Forces of Ukraine by providing the operational forecasts of oceanographic conditions}

\section{Annotation}

The work aimed to solve the problem of ensuring the security and defense capabilities of Ukraine. Creation of the modern automated system for forecasting of oceanographic parameters of the marine environment of the Ukrainian part of the Azov-Black sea to meet the needs of the Ukrainian Armed Forces. For this purpose, the prospects of using an adapted software package (integrated numerical models Delft3D: FLOW + WAVE (SWAN Simulating WAves Nearshore) using meteorological data from the model GFS (Global Forecast System) considered.

The results of tests of the complex for solving problems of diagnosis and forecast of oceanographic conditions for the Odesa region in the north-western part of the Black Sea are given.

The set of oceanographic data that can be obtained using the current version of the automated model complex includes:

wind conditions;

deviation of the sea level from the undisturbed state under the action of the wind in the coastal zones of the sea (which determine the current depths);

spatio-temporal variability of parameters of wind waves, water circulation (currents) in coastal areas of the sea, taking into account the influence of wind waves;

defined tasks will allow to solve the application of the automated forecasting complex in the interests of navigation and hydrographic support of the naval forces of the Armed Forces of Ukraine.

It is concluded that the integration of the automated complex "Delft3D-FLOW + SWAN" in the structure of the intelligent information system for lighting the hydrographic situation in the Black Sea will solve the problem of rapid assessment of the oceanographic situation in the present (up to 5 days) and future (up to 4 days) for the Black Sea and its north-western part, selected areas of coastal zones with the necessary spatial separation of data.

Keywords: Black Sea; oceanographic conditions; prognostication; model complex; navigation and hydrographic support of the Ukrainian Navy. 